\title{
Gamifying Teaching Elementary English: Word Search Game to Reach Vocabulary Mastery
}

\author{
Devi Novita Sari Simatupang ${ }^{1}$, \& Tatum Derin ${ }^{2}$ \\ ${ }^{1}$ SD Swasta Karya Tani Kandis. Indonesia \\ ${ }^{2}$ U-Raise Academy, Pekanbaru. Indonesia
}

\begin{abstract}
ARTICLE HISTORY
Received : 2019-08-02

Revised : 2019-08-27

Accepted : 2020-07-20
\end{abstract}

\section{KEYWORDS}

Word Search

Gamification

ELT

EFL

Vocabulary

\begin{abstract}
The purpose of the research is to find out whether there is any significant effect of the word search game compared to the board game towards the students' vocabulary mastery at the fourth grade SD Swasta Karya Tani Kandis. The design used in this research is experimental research. The location for this research was at SD Swasta Karya Tani Kandis. The vocabulary test was used to find out the students' ability in vocabulary. The result of this research shown that the data obtained from the students' pre-test to find the homogeneity to see the equal ability from both classes. and post-test scores of experimental classes 1 and 2 to know the different scores of two experimental classes. The test was to answer the questions based on the vocabulary test. Before treatment, the researcher gave the pre-test to IVA (experiment class 1) and IVB (experiment class 2). The researcher taught within 6 (Six) meetings including pre-test and post-test. Based on the data analysis it can be seen that Sig $<0,000$. The value of sig (2-tailed) was 0.03 and it was lower than significant probabilities $5 \%(\mathrm{P}<$ 0.05 ) in post-test experimental classes 1 and 2 . Furthermore, there is a significant effect of using Word Search Game toward students' vocabulary mastery fourth grade SD Swasta Karya Tani Kandis between experimental groups 1 and 2 . In conclusion, there was a significant effect of using Word Search Game toward students' vocabulary mastery.
\end{abstract}

\section{Introduction}

Vocabulary holds a crucial part in English. It contributes as well as an essential meaning to comprehend the foreign language (Nuratika, Yanti, \& Mayer, 2019). In academia, vocabulary has a big part in supporting everyone to communicate with other people and comprehend meaning in the written word (Arisman, Hamra, \& Weda, 2017). Furthermore, we still convey our expression without grammar but without vocabulary, there is little that can be conveyed (Alhamdi, Salih, \& Abd, 2019). Vocabulary is an important part of learning English because it supports students to communicate with other people and comprehend words in interaction in the language (Amin, 2020; Derin \& Hamuddin, 2019).

For many students, it is not easy for them to master vocabulary. English teacher has responsibility in establishing and guiding students to connect the meaning of almost countless words in students' minds (Putri, Hamuddin, Nursafira, \& Derin, 2020). It is the teacher's responsibility to find the best solution to make all the students easily in memorizing the vocabulary. Based on the preliminary, research conducted at SD Swasta Karya Tani Kandis, the researcher found that most of the students at the fourth-grade students of the school still found difficulties in mastering vocabulary. This was supported by the result of an interview with the English teacher, Wella Jayanti, S.Pd. He said that most of the students in fourth grade had difficulties in mastering English, especially vocabulary. It is because they are difficult to memorize the vocabulary, and their vocabulary mastery was low.

In teaching vocabulary, a method or technique used to present the lesson, such as a game. Game is one of interesting instrument that used to attract students' to follow the teaching and learning process. Games are associated with a feeling of happiness (Rizky, 2020). For this reason, most learners appreciate games even if they are not familiar with the rules. Games are the perfect instrument to motivate and make the students participate in the teaching and learning process. When games and education are combined, it can be educative and education environments can be entertaining (Troussas, Krouska, \& Sgouropoulou, 2020). The learners who learned with games, gain positive attitudes, and can be more motivated while learning.

Word search game is what interests this study because it has been proven to have advantages and effectiveness in learning vocabulary. First, games bring relaxation and fun for students. Second, games usually involve friendly competition and they keep learners interested. When playing games, students study English structures easily in a relaxed 
atmosphere. Through games, English teachers can motivate his/her students in learning English. The goal of this is to find and mark all the words hidden inside the box. The words may be horizontally, vertically, or diagonally. Sometimes a list of the hidden words is provided, but for more challenging s, let the player figure them out. Many word search $s$ have a theme related to all the hidden words.

Therefore, this study sees using is one of the alternative techniques to increase students' interest in learning vocabulary. Teaching vocabulary through word search enables the students to find out information or guess the meaning of unfamiliar words. So, the word search can help the students. The students will be happy and interested in learning. They also try to know the new words from word search. Teaching vocabulary through word search is not only in written activities. We can make it fun so it would make the passive learners enjoy the process.

\section{Literature Review}

Vocabulary is a list of words with their meanings, especially in a book for learning a foreign language (Schmitt \& Schmitt, 2020). Vocabulary, to a content area, is as unique as fingerprints are to a human being. A content area is distinguishable by its language, particularly the special and technical terms that label the concepts under the subject matter (Anders \& Guzzetti, 2020). Vocabulary is a core component of language proficiency and provides much of the basis for how well learners speak, listen, read, and write. The teachers know they must do something with the language of their content areas and provides the basics for how well learners speak, listen, read, and write. This study seen vocabulary as seen is the total number of words that are needed to communicate ideas and express the speakers' meaning. Learners must master the vocabulary so that they can comprehend the sentence or utterance. The learner should master the vocabulary because it is central to the English language because without sufficient vocabulary students cannot understand others or express their ideas.

Derin, Nursafira, Yudar, Gowasa, \& Hamuddin (2020) said that a lack of vocabulary knowledge impedes language comprehension and production. He also said that to get native-like mastery over a language, learners must learn thousands of words. It can be concluded that without words to express a wider range of meanings, communication in an L2 just cannot happen in any meaningful way. Then, vocabulary can be said as a crucial part of mastering four English skills because all skills need vocabulary. Thornbury (2002) stated that teaching vocabulary plays an important role in language acquisition because the mastery of vocabulary will help students to master all the language skills (speaking, listening, writing, and reading).

The vocabulary mastery cannot be done spontaneously but step by step. Carpenter \& Geller (2020) mentioned that there are at least three steps in processing vocabulary mastery. First is the children period, this term children can define concept vocabulary to say their concrete idea. Second is the adolescent period, this term is the adolescent start to use the language and make it more extensive directly in simple communication. Third is the adult period, this term the vocabulary is used more and more intensively because they make more communication with each other.

It can be concluded that vocabulary is very important in learning language and mastering vocabulary. It will facilitate someone in using the language for communication. So, this study intends to improve students' vocabulary with a technique that piques students' interest. To achieve this, the researcher uses the educational game called word search game. Word Search, also known as word find games, are popular for helping students recognize words. Some words go across and some go down. It is similar with the word search game. The students have to find the entire letter that hidden in the grid. Words will be hidden inside the letters, written horizontally and vertically. It can be concluded that word search and word find is the same. This game can be used for increasing students' vocabulary development.

Historically, the word search game was originally designed and published by Norman E. Gibat in the Selenby Digest on March 1, 1968, Oklahoma. The game was very popular and several more followed this original design. Some teachers in the Norman schools asked for reprints to use in their classes. One teacher sent them around the country to various friends in other schools. Undoubtedly one of these scattered copies eventually led somebody to sell the idea to a syndicator. Word search consists of letters arranged in a grid, containing several hidden words written in any direction. It means that word search contains several hidden words on letters arranged in a grid.

To success in teaching vocabulary through word search, the teacher should have different technique for different level. Teaching vocabulary through word search enables the students to find out information or guess the meaning on unfamiliar words. The students will be happy and interesting in learning and they always try to know the new words from word search . Relating to the importance of teaching vocabulary through word search, as far as it is known, some students are always confused with the problem. In this case, there are many ways to making the students interested in what they are learning. The teacher can create a game, the student can think about new words 
that related with the topic of word search . Teaching vocabulary by using word search make students more relax, enjoyable, and happy. It is also helps the students understanding the material and improves their achievement. Children without an extensive vocabulary have a hard time understanding what they're reading, especially as they get older, and reading material becomes more difficult.

\section{Method}

This experimental research used "one group pretest-post-test design" by comparing the experimental group 1 and experimental group 2. The experimental class 2 was taught by using word game labeled as an experimental group while the other class is the experimental group used Board game.This research consisted of two variables: independent variable and dependent variable. Seawright (2016) states that independent variable is variable that experimenter expects to influence to others, whereas he states that dependent variable is a variable upon which the independent variable is acting. It meant that the independent variable (X) affected the dependent variable (Y). In this research, the independent variable (X) referred to word game that affects the dependent variable (Y) referred to students' vocabulary. The design was as follows:

Table 1. Research Design

\begin{tabular}{lccc}
\hline Class & Pre-test & Treatment & Post-test \\
\hline Experiment & $\mathrm{X}_{1}$ & $\mathrm{~T} 1$ & $\mathrm{X}_{2}$ \\
Control & $\mathrm{Y}_{1}$ & $\mathrm{~T} 2$ & $\mathrm{Y}_{2}$ \\
\hline
\end{tabular}

Based on the table $1, \mathrm{X}_{1}$ is the students' vocabulary mastery treatment of experimental group $1 . Y_{1}$ is the students' vocabulary mastery before treatment of experimental group 2 T1: Teaching vocabulary mastery by using Word game. T2 is teaching vocabulary mastery by using Board game. $\mathrm{X}_{2}$ is the students' vocabulary mastery after treatment of experimental group $1 . \mathrm{Y}_{2}$ is the students' vocabulary mastery after treatment of experimental group 2

The location for this research was at SD Swasta Karya Tani Kandis. The researcher taught in this school so that the researcher knew the problem in English is subject in this school. Population is also known as a well-defined collection of individuals or objects known to have similar characteristics. The population of this research was the six year students of SD Swasta Karya Tani Kandis. They consisted of 50 students at first year students of SD Swasta Karya Tani Kandis. In determining the sample of this research, the researcher used random assigned by selecting two classes. The sample of this class was IV A in experimental group 1 and IV B and experimental group 2 .
Table 2. Research Population and Sample

\begin{tabular}{cc}
\hline Class & Population \\
\hline IV A & 25 \\
IV B & 25 \\
\hline Total & 50 \\
\hline
\end{tabular}

The vocabulary test was used to find out the students' ability in vocabulary. The indicators were based on syllabus and Lesson Plan. The tests consisted of 20 items in each test, the indicators of the test were: a) find the words in the game, b) find the meaning of the words. The form of test was made in the blue print of following form:

Table 3. Research Instrument Blueprint

\begin{tabular}{clc}
\hline Test & \multicolumn{1}{c}{ Topic } & $\begin{array}{c}\text { Number } \\
\text { of } \\
\text { Question }\end{array}$ \\
\hline Pre Test & $\begin{array}{l}\text { Career } \\
\text { Things in the }\end{array}$ & 10 \\
& School & 10 \\
\hline Post Test & Family Member & 10 \\
& Vegetable & 10 \\
\hline
\end{tabular}

The first part of the exam is about filling in the blanks of 10 items. The students must choose the correct answer in the in word search sheet. The total score is 10 for each answer. The second part is to find the definition, this score will be score as 10 for each answer.

The indicators of the test are as follows:

\section{1) Validity}

The validity of an assessment measure or tool indicated the extent to which it was an adequate measure of the curriculum and objectives it represented. Validity was the most important consideration in developing and evaluating measuring instruments. The focus of recent views of validity was not on the instrument itself but on the interpretation and meaning of the scores derived from the instrument (Ary et al, 2010). There were several types of validity, but the most important type for classroom teachers to understand was content validity. Content validity is not separated from construct validity. In fact, construct validity is the prerequisite for content validity (Almanasreh, Moles, \& Chen, 2019). It meant that content validity attained when there was a close matching between the content of the assessment and of the curriculum and instruction. When students were assessed on the material that they had been studying in the classroom, the assessment measure could have content validity. In this test, the researcher asked students to answer the matching test and arranging the scrabble vocabulary to measure students' mastery in learning vocabulary. 


\section{2) Reliability}

Reliability of a measuring instrument was the degree of consistency which it measured whatever it was measuring. This quality was essential in any kind of measurement. The teacher used such measuring instruments to identify and used techniques that helped the teacher determine to what extent their measuring instruments are consistent and reliable (Barrows et al., 2019). To make sure that the instrument (test) was reliable, the researcher set test vocabulary prompt and scoring rubric so that students could use it as their borders to produce a final version of their vocabulary.

As mentioned previously, two classes were used in this research. The first classes, grade IVA, was selected as the experimental class 1 and the second, grade IV B was designed as the experimental class 2 . Both classes were tested by using pre test. The students in experimental class 1 were taught by using word game in experiment group while experimental class 2 were taught by Board game. The materials were same as the material in both groups. The length of the teaching learning process was 6 meetings. After the students finish doing the activity, the researcher reviewed and evaluated the progress of teaching and learning process to know whether the strategy works well or not. In every meeting, the researcher led them to do the same activities with different topic to improve their reading comprehension. The last meeting was posttest for both classes. The data was analyzed statically to know the result whether it is statistically significant or not between experimental class 1 and 2 class by using Word Search Game and board game. It was analyzed by using T-test if the data were normal and homogeneous, and use UMann-Whitney-Test if the data were not normal and homogeneous. The result data then calculated to get the average score.

To analyzed the data of pre-test and post-test, the researcher used Software Statistical Package for Social Science (SPSS) for windows 21.0 before hypothesis test, first was done the normality test distribution data and homogeneity variance data both of classes. Testing normality distribution data in this research was done using test Kolmogorov Smirnov (KS-21) in program SPSS version 21.0, while Levene Test for testing homogeneity of sample. After normality and homogeneity test, the result data calculated the average of the score. The researcher used N-Gain between pre-test and post-test. The formula to find out the result of normality test, homogeneity test, and also the avarege of the score as follows:

\section{1) N-Gain}

$\mathrm{N}$-Gain is used to know the proportion of actual again (pre-test and pre-test) with maximum gain that will be achieved. Then, N-Gain interpreted by using the criteria achievement $\mathrm{N}$-Gain score. In this research, N-Gain formula used to know the effect size of the students' reading comprehension by using Word Search Game. The formula of N-Gain score as follow:

$$
\begin{aligned}
& \mathbf{N - G a i n}=\mathbf{S}_{\text {post }}-\mathbf{S}_{\text {pre }} \\
& \qquad \mathbf{S}_{\max }-\mathbf{S}_{\text {pre }} \\
& \text { Note: } \\
& \mathrm{S}_{\text {post }} \text { : Post-test score } \\
& \mathrm{S}_{\text {pre }}: \text { Pre-test score } \\
& \mathrm{S}_{\max } \text { : Maximum ideal score }
\end{aligned}
$$

Table 4. The Criteria Achievement N-Gain Score

\begin{tabular}{cc}
\hline Limitation & Category \\
\hline $\mathrm{g}>0,7$ & High \\
$0,3<\mathrm{g}<0,7$ & Middle \\
$\mathrm{g} \leq 0,3$ & Low \\
\hline
\end{tabular}

\section{2) T-test}

T-test is a parametric statistic used to test the hypothesis, comparative average of two samples, when the data are interval or ratio form. T-test is used when data is normal and homogeneous. To determine the normal and homogeneous data, it uses normality and homogeneity test.

\section{Results}

Dealing with the data analysis and interpretation which have been taken from the pretest and posttest from the experimental 1 and 2 . The aim of this research was to obtain the significant effect of the students' vocabulary mastery between those students who were taught by using Word Search Game and those who were not. The data were obtained from the students' post-test scores of experimental 1 and 2. The vocabulary test is used to find out the students' ability in vocabulary. The indicators were based on syllabus and Lesson Plan. The tests consisted of 20 items in each test, the indicators of the test are: a) find the words in the game, b) find the meaning of the words.Before treatment, the researcher gave the pretest to IVA (experiment class 1) and IVB (experimental class 2).The researcher taught within 6 (Six) meetings including pre-test and post-test. This research had been done in three steps; pretest, treatment and posttest.

The data were obtained from the students' posttest scores of experimental and control class. The test was to answer the questions based on the text in Essay. Before treatment (only for experimental class), the researcher gave the pre-test to IVA (experiment class 
1) and IVB (experimental class 2).The researcher taught within 6 (Six) meetings including pre-test and post-test. The data were from the score of the improvement of the vocabulary mastery from pre-test to post-test for both experimental classes. In giving test; pre-test and post-test. The data gathered in this research were all information related to the effect of Word Search Game toward students' vocabulary mastery.

\subsection{Pre-Test Results}

Before the researcher began doing treatment, the researcher did pre test in order to find out the students achievements is normal and homogenous or not.

\section{1) Normality Test}

Normality test is a test to measure whether our data has normal distribution or not. Normal distribution is a symmetrical, bell-shaped distribution of data that has specific properties and is used as a reference point for comparing the shapes of data distribution. A test is called normal if the result indicate that few numbers of participants are at the right and left tails and most of participants are in the middle. It shows the symmetrical and one cluster of the data in the middle. To investigate the normality testing, the researcher use Kolmogorov-Smirnov test by using SPSS 22.0 program.

Table 5. Pre-test Normality Test

\begin{tabular}{ccccc}
\hline Class & $\begin{array}{c}\text { Asymp.Sig. } \\
\text { (2-tailed) }\end{array}$ & $\boldsymbol{\alpha}$ & Hypothesis & Distribution \\
\hline Exp 1 & 0.434 & 0.05 & Accept Ha & Normal \\
Exp 2 & 0.510 & 0.05 & Accept Ha & Normal \\
\hline
\end{tabular}

From the table 5, it can be analysed that the data distribution was normal. It was proven by the significant number of the test. The significant number in experimental class 1 and 2 were 0.434 and 0.510 . Furthermore, the significant number was higher than significance a 0.05 . It means that the distribution data of pre-test in experimental class was normal.

\section{2) Homogeneity Test}

The researcher did the homogeneity test by using levene test formula in SPSS. Homogeneity test was conducted to determine homogeneity sample. Thus, it was analyzed by comparing value of based on trimmed mean with the level significant level 0.05 . The result of homogeneity in experimental class 1 and 2 was taken from pre-test of both classes class could be described from the table 6 .

Table 6. Pre-test Homogeneity Test test

From the table 6 , it can be summarized that the data was homogenous. It can be seen in the comparison between trimmed mean score with significant $a$. The significance of trimmed mean was lower than significant $5 \%, 0.633>0.05$. It means that the data pre-test score in experimental class 1 and 2 were homogeneous.

\subsection{Post-test Results}

The achievements of post-test in experimental classes 1 and 2 were different. Here, the researcher compare the post test of $\mathrm{c}$ in experimental class 1 and 2 score with board game as could be described by this following table.

Table 7. Students' Post-test Results

\begin{tabular}{|c|c|c|c|c|c|}
\hline Students & $\begin{array}{c}\operatorname{Exp} \\
1 \\
\end{array}$ & $\begin{array}{c}\text { Category } \\
1 \\
\end{array}$ & Students & $\begin{array}{c}\operatorname{Exp} \\
2 \\
\end{array}$ & $\begin{array}{c}\text { Category } \\
\mathbf{2} \\
\end{array}$ \\
\hline Student 1 & 75 & Good & $\begin{array}{c}\text { Student } \\
1\end{array}$ & 75 & Good \\
\hline Student 2 & 85 & $\begin{array}{l}\text { Very } \\
\text { Good }\end{array}$ & $\begin{array}{c}\text { Student } \\
2\end{array}$ & 65 & Good \\
\hline Student 3 & 85 & $\begin{array}{l}\text { Very } \\
\text { Good }\end{array}$ & $\begin{array}{c}\text { Student } \\
3\end{array}$ & 90 & $\begin{array}{l}\text { Very } \\
\text { Good }\end{array}$ \\
\hline Student 4 & 85 & $\begin{array}{l}\text { Very } \\
\text { Good }\end{array}$ & $\begin{array}{c}\text { Student } \\
4\end{array}$ & 65 & Good \\
\hline Student 5 & 70 & Good & $\begin{array}{c}\text { Student } \\
5\end{array}$ & 65 & Good \\
\hline Student 6 & 75 & Good & $\begin{array}{c}\text { Student } \\
6\end{array}$ & 55 & Fair \\
\hline Student 7 & 85 & $\begin{array}{l}\text { Very } \\
\text { Good }\end{array}$ & $\begin{array}{c}\text { Student } \\
7\end{array}$ & 70 & Good \\
\hline Student 8 & 85 & $\begin{array}{l}\text { Very } \\
\text { Good }\end{array}$ & $\begin{array}{c}\text { Student } \\
8\end{array}$ & 70 & Good \\
\hline Student 9 & 80 & Good & $\begin{array}{c}\text { Student } \\
9\end{array}$ & 75 & Good \\
\hline $\begin{array}{c}\text { Student } \\
10\end{array}$ & 80 & Good & $\begin{array}{c}\text { Student } \\
10\end{array}$ & 70 & Good \\
\hline $\begin{array}{c}\text { Student } \\
11\end{array}$ & 85 & $\begin{array}{l}\text { Very } \\
\text { Good }\end{array}$ & $\begin{array}{c}\text { Student } \\
11\end{array}$ & 75 & Good \\
\hline $\begin{array}{c}\text { Student } \\
12\end{array}$ & 85 & $\begin{array}{l}\text { Very } \\
\text { Good }\end{array}$ & $\begin{array}{c}\text { Student } \\
12\end{array}$ & 70 & Good \\
\hline $\begin{array}{c}\text { Student } \\
13\end{array}$ & 80 & Good & $\begin{array}{c}\text { Student } \\
13\end{array}$ & 65 & Good \\
\hline $\begin{array}{c}\text { Student } \\
14\end{array}$ & 100 & $\begin{array}{l}\text { Very } \\
\text { Good }\end{array}$ & $\begin{array}{c}\text { Student } \\
14\end{array}$ & 65 & Good \\
\hline $\begin{array}{c}\text { Student } \\
15\end{array}$ & 75 & Good & $\begin{array}{c}\text { Student } \\
15\end{array}$ & 65 & Good \\
\hline $\begin{array}{c}\text { Student } \\
16\end{array}$ & 85 & $\begin{array}{l}\text { Very } \\
\text { Good }\end{array}$ & $\begin{array}{c}\text { Student } \\
16\end{array}$ & 70 & Good \\
\hline $\begin{array}{c}\text { Student } \\
17\end{array}$ & 80 & Good & $\begin{array}{c}\text { Student } \\
17\end{array}$ & 70 & Good \\
\hline $\begin{array}{c}\text { Student } \\
18\end{array}$ & 85 & $\begin{array}{l}\text { Very } \\
\text { Good }\end{array}$ & $\begin{array}{c}\text { Student } \\
18\end{array}$ & 70 & Good \\
\hline $\begin{array}{c}\text { Student } \\
19\end{array}$ & 75 & Good & $\begin{array}{c}\text { Student } \\
19\end{array}$ & 70 & Good \\
\hline $\begin{array}{c}\text { Student } \\
20\end{array}$ & 100 & $\begin{array}{l}\text { Very } \\
\text { Good }\end{array}$ & $\begin{array}{c}\text { Student } \\
20\end{array}$ & 70 & Good \\
\hline $\begin{array}{c}\text { Student } \\
21\end{array}$ & 85 & $\begin{array}{l}\text { Very } \\
\text { Good }\end{array}$ & $\begin{array}{c}\text { Student } \\
21\end{array}$ & 70 & Good \\
\hline $\begin{array}{c}\text { Student } \\
22\end{array}$ & 85 & $\begin{array}{l}\text { Very } \\
\text { Good }\end{array}$ & $\begin{array}{c}\text { Student } \\
22\end{array}$ & 65 & Good \\
\hline $\begin{array}{c}\text { Student } \\
23\end{array}$ & 85 & $\begin{array}{l}\text { Very } \\
\text { Good }\end{array}$ & $\begin{array}{c}\text { Student } \\
23\end{array}$ & 70 & Good \\
\hline Student & 95 & Very & Student & 80 & Good \\
\hline
\end{tabular}




\begin{tabular}{cccccc}
24 & & Good & 24 \\
$\begin{array}{c}\text { Student } \\
25\end{array}$ & 85 & $\begin{array}{c}\text { Very } \\
\text { Good }\end{array}$ & $\begin{array}{c}\text { Student } \\
25\end{array}$ & 70 & Good \\
\hline Total & 2090 & & Total & 1745 & \\
\hline Mean & 83.60 & & Mean & 69.80 & \\
\hline
\end{tabular}

Table 10 showed that the students result in vocabulary mastery. From the data it showed that the mean score in experimental class 1 was 83,60 and the experimental class 2 was 69,80 . The following table was the distribution of frequency of students in posttest in experiment class 1 and 2:

Table 8. Descriptive Statistic of the Post-test Results

\begin{tabular}{cccccc}
\hline \multirow{2}{*}{ Class } & \multirow{5}{c}{ N } & \multicolumn{3}{c}{ Mastery Score } & \multirow{2}{*}{ Average } \\
& & Ideal & Min & Max & \\
\hline Exp 1 & 25 & 100 & 70 & 100 & 83.60 \\
Exp 2 & 25 & 100 & 55 & 90 & 69.80 \\
\hline
\end{tabular}

From the table 8 , it can be concluded that the mean score of post -test in experimental class 1 was 83,60 with the minimum score was 70 and the maximum score was 100 . While, the mean score of experimental class 2 was 69,80 with the minimum score was 70 and the maximum score was 90 . In line with the statement before, it can be summarized that the post-test score of experimental class 1 was higher in Experiment 2. It was caused by there is the effect of the use of words search games.

To know the students' increase between both of classes, it can be seen in the following diagram:

Diagram 1. Comparison of Experimental Classes' Post-test Scores

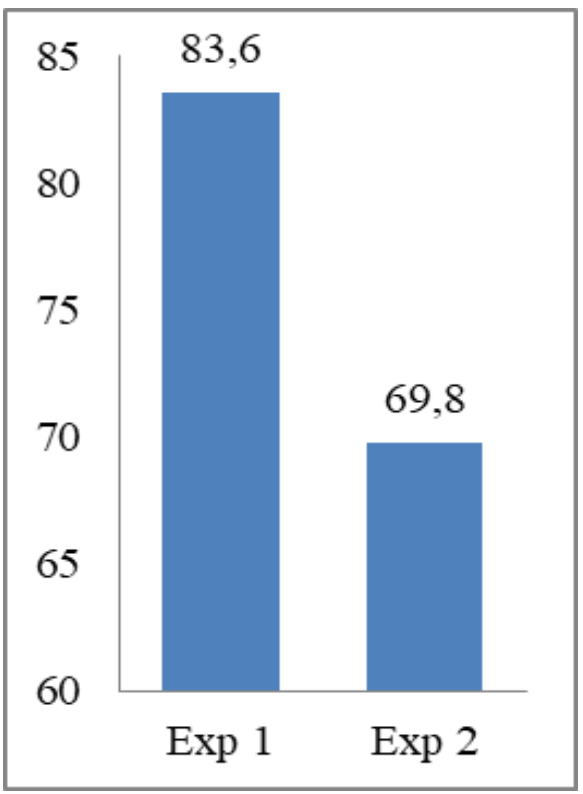

From the diagram 1, it can be seen the post-test score of experimental class 1 was higher than experimental class 2. The comparison of the score was $83,60>69,80$. It means that the words search games had the positive effect towards students' vocabulary mastery than board game. Furthermore, the researcher supported the data by using several test to know the normality data, homogeneity, and the significant difference of the test.

Table 9. Post-test Normality Test

\begin{tabular}{ccccc}
\hline Class & $\begin{array}{c}\text { Asymp.Sig. } \\
\text { (2-tailed) }\end{array}$ & $\boldsymbol{\alpha}$ & Hypothesis & Distribution \\
\hline Exp 1 & 0.210 & 0.05 & Accept Ha & Normal \\
Exp 2 & 0.320 & 0.05 & Accept Ha & Normal \\
\hline
\end{tabular}

From the table 9, it can be analyzed that the data distribution was normal. It was proven by the significant number of the test. The significant number in experimental 1 and 2 was 0.210 and 0.320 . Furthermore, the significant number was higher than significance 0.05 . It means that the distribution data of post-test in experimental class 1 and 2 were normal.

Table 10. Post-test Homogeneity Test

\begin{tabular}{ccccc}
\hline Data & $\begin{array}{c}\text { Trimmed } \\
\text { Mean }\end{array}$ & $\boldsymbol{\alpha}$ & Hypothesis & Distribution \\
\hline Post-test & 0.447 & 0.05 & Accept H0 & Homogeneous \\
\hline
\end{tabular}

From the table above, it can be summarized that the data was homogenous. It can be seen in the comparison between trimmed mean score with significant. The significance of trimmed mean was higher than significant $5 \%, 0.474>0.05$. it means that the data of post test score in experimental classes class were homogeneous.

Table 10. Post-test T-test

\begin{tabular}{ccccc}
\hline Data & $\begin{array}{c}\text { Asymp.Sig. } \\
\text { (2-tailed) }\end{array}$ & $\boldsymbol{\alpha}$ & Hypothesis & Distribution \\
\hline Post-test & .000 & 0.05 & Accept Ha & $\begin{array}{c}\text { Different } \\
\text { significance }\end{array}$ \\
\hline
\end{tabular}

Based on the table above, the Asymp.sig (2-tailed) was 0.000 . It was lower than significant level (0.05). It means that $0.000<0.05$. It can be concluded that there is difference significant effect between experimental class 1 and 2 .

To know the effect of treatment that was given to experimental class 1 and 2, the researcher used N-Gain score. Before calculating N-Gain of pre-test and posttest both of classes, it should be calculated Gain score of pre-test and post-test of experimental class 1 and 2 diagram below: 
Diagram 2. Difference of Average Scores of Both Classes

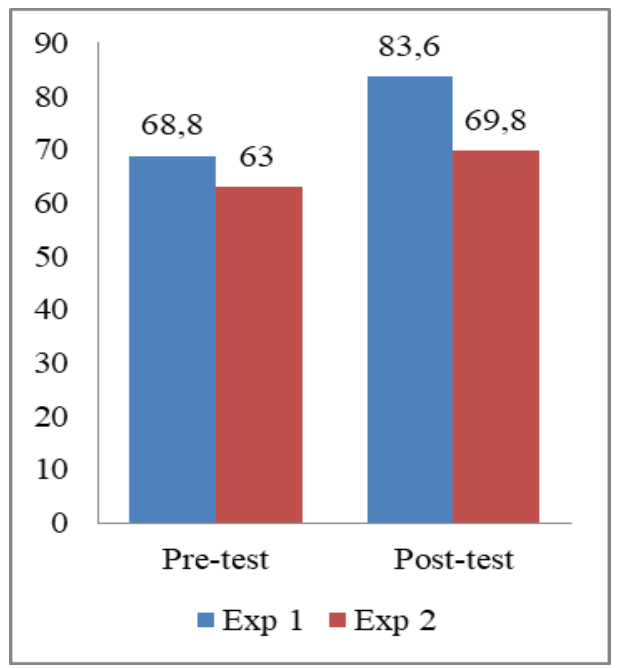

The diagram 2 has been cleared that experimental class 1 students were influenced by words search game. It could be analyzed in diagram above. Therefore, the difference of Gain score both of classes can be seen in the following diagram.

Diagram 3. Difference of N-Gain Score in Both Classes

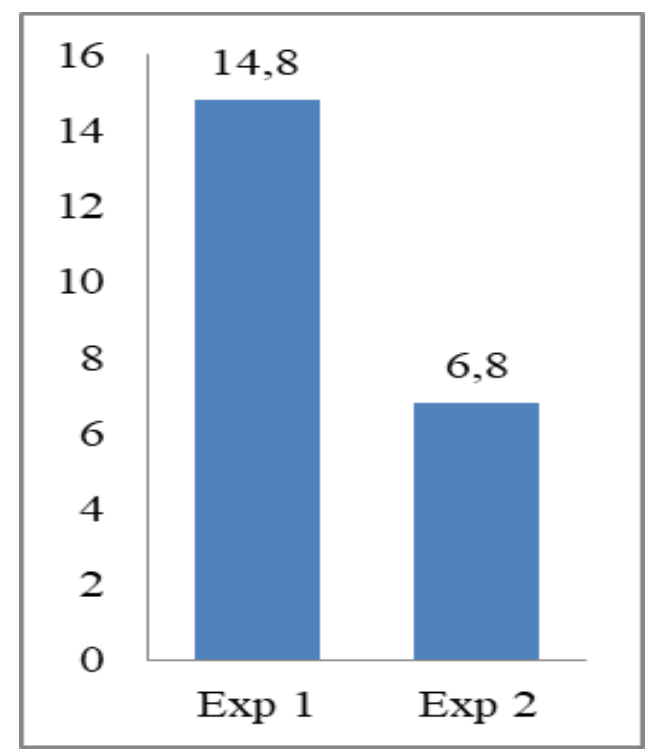

From diagram 3 it can be seen that the difference gain of each classes was very significant. Gain score in Experiment 1 was 14,80 While, in experimental class 2, the gain score was 6.80. It means that gain score in Experiment 1 was higher than experimental class 2.

Moreover, to know the increase of the students or the students' comprehension after teaching and learning process, it can be used by comparing the ngain score in each class with criteria an achievement of N-Gain value Therefore, the comparison can be compared in the following table.

Table 11. N-Gain Scores of Both Classes

\begin{tabular}{lcccc}
\hline & N & Min & Max & Average \\
\hline Exp 1 & & & & \\
\hline Pre & 25 & 45 & 90 & 0.47 \\
Post & 25 & 70 & 100 & \\
\hline Exp 2 & & & & \\
\hline Pre & 25 & 40 & 90 & 0.09 \\
Post & 25 & 45 & 90 & \\
\hline
\end{tabular}

From table 11 above, it can be explained that $n-$ gain score in experimental class 1 was 0.47 . It means that $\mathrm{g}>0.3$, it was included in middle category. While, in experimental class 2 , the researcher found $\mathrm{n}$-gain score was 0.09 and it lower than 0.3 . it means that $n$ gain in experimental class 2 was included in low category. According to the fact above, it can be concluded that there is positive effect of Word Search Game toward students' Vocabulary in fourth grade SD Swasta Karya Tani Kandis.

\section{Discussion}

Based on the data above, the researcher proved that the Word Search game was effective for students' Vocabulary in fourth grade SD Swasta Karya Tani Kandis. It was also supported by students' experimental class score that increasing after applying Word Search Game. Based on the presentation of data analyzing above, there was an increasing score in students' experimental class. In the result of post-test, the differences in mean score from both classes are quite big. The experimental class had 83,60 more better than the other class that only had 69,80 .

The descriptive statistics of both class also had quite gap. The minimum score for the treatment class was 70, quite higher than the other one, which was 55. While in the treatment class, some students got perfect score, in the other class, the highest score was 90.

The data had normal distribution that proven by The significant number in experimental 1 and 2 was 0.210 and 0.320 . Furthermore, the significant number was higher than significance 0.05 . The data also homogeneous that proven by the comparison between trimmed mean score with significant. The significance of trimmed mean was higher than significant $5 \%, 0.474>0.05$. it means that the data of post test score in experimental classes class were homogeneous.

To know whether there is any significant differences, the researcher calculated the data by using parametric statistic (T-test). The data showed that the Asymp.sig (2-tailed) was 0.000. It was lower 
than significant level $(0.05)$. It means that $0.000<$ 0.05 . It can be concluded that there is difference significant between experimental class 1 and 2 .

Later, to know the effect of treatment given to both of the class, the researcher used N-Gain score. The result of it was n-gain score in experimental class 1 was 0.47 . It means that $g>0.3$, it was included in middle category. While, in experimental class 2 , the researcher found n-gain score was 0.09 and it lower than 0.3. it means that $n$-gain in experimental class 2 was included in low category.

Mastering vocabulary is important in learning language especially English, because the potential knowledge that can be known about a word is rich and complex (Rahman, Abbas, Hasyim, 2019; Risani, 2020). Due to the complexity of word, we have to find out the best way to enrich students' vocabulary. Without vocabulary, mastery to express a wider range of meanings, communication cannot happen in any meaningful way.

This research is line with research of Damayanti (2014) whose investigation was concerned to know the students' mastery on vocabulary after applying the word search game. The instrument to collect the data is test that consists of two varieties. First, the researcher gives pre-test to the students about vocabulary20 items of multiple choices. Second, the write gives post-test to the students about the vocabulary 20 items of multiple choice questions. The data obtained is statistically analyzed by SPSS 16 . This analysis is test of the hypothesis. The result of SPSS 16 computing showed there is significant effect of using word search puzzle technique on students' achievements in vocabulary is accepted, from the result, it can be seen that word search technique it seems can serve as a suitable technique toward their vocabulary mastery.

Learning vocabulary through games was also had attained a lot of attention. The value of educational games has been increasing in language education since they help to make language education entertaining (Mohsen, Abdollahi, \& Omar, 2019). When games and education are combined, it can be educative and education environments can be entertaining. The learners who learned with games, gain positive attitudes and can be more motivated while learning.

In word search game, The students have to find the entire letter that hidden in the grid. Words will be hidden inside the letters, written horizontally and vertically. This game can be used for increasing students' vocabulary development by finding the meaning of the vocabulary. Teaching vocabulary by using word search game makes students more relaxed, enjoyable, and happy. It is also helps the students understanding the material and improves their achievement While playing board game, students can learn English they way children learn their mother tongue without being aware they are studying; thus without stress, they can learn vocabulary a lot by answering the question on the board game.

\section{Conclusion}

In this research, the data were obtained from the students' pre-test and post-test scores of experimental class 1 and 2. The test was based on the vocabulary test. Before treatment, the researcher gave the pre-test to IVA (experimental class 1) and IVB (experimental class 2). The researcher taught within 6 (Six) meetings including pre-test and post-test.

$\mathrm{Ha}$ is accepted if $\mathrm{Sig}<0,005$ or there is significant effect of using Word Search Game toward students' vocabulary mastery fourth grade SD Swasta Karya Tani Kandis. Ho is accepted if Sig > 0,005 or there is no significant effect of using Word Search Game toward students' vocabulary mastery fourth grade SD Swasta Karya Tani Kandis. Based on the calculation, we could see that Sig $<0,000$. The value of sig (2-tailed) was 0.000 and it was lower than significant probabilities $5 \%(\mathrm{P}<0.05)$ in postest experimental 1 and 2. Furthermore, there is a significant effect of using Word Search Game toward students' vocabulary mastery fourth grade SD Swasta Karya Tani Kandis between experimental Group 1 and 2. Based on the research it can be seen that there was a significant difference of significant effect of using Word Search Game toward students' vocabulary mastery fourth grade SD Swasta Karya Tani Kandis.

\section{References}

Alhamdi, M. M. H., Salih, S. B., \& Abd, M. A. A. (2019). The Impact of Learning Technology on Some Motor Skills of Deaf and Mute Students in Comparison with Healthy Students. Indian Journal of Public Health Research \& Development, 10(10), 828-831.

Almanasreh, E., Moles, R., \& Chen, T. F. (2019). Evaluation of methods used for estimating content validity. Research in Social and Administrative Pharmacy, 15(2), 214-221.

Amin, A. (2020). Attitude Towards Language in Sociolinguistics Settings: A Brief Overview. REiLA: Journal of Research and Innovation in Language, 2(1).

Anders, P. L., \& Guzzetti, B. J. (2020). Literacy instruction in the content areas. Routledge.

Arisman, R., Hamra, A., \& Weda, S. (2017). Lecturer's Competence and Students' Writing Proficiency at University Level in Indonesia. ELT WORLDWIDE, 4(2), 161-170. 
Barrows, C., Bloom, A., Ehlen, A., Ikäheimo, J., Jorgenson, J., Krishnamurthy, D., ... \& Staid, A. (2019). The IEEE reliability test system: A proposed 2019 Update. IEEE Transactions on Power Systems, 35(1), 119-127.

Carpenter, S. K., \& Geller, J. (2020). Is a picture really worth a thousand words? Evaluating contributions of fluency and analytic processing in metacognitive judgements for pictures in foreign language vocabulary learning. Quarterly Journal of Experimental Psychology, 73(2), 211224.

Damayanti, R. (2014). Teaching Vocabulary Trough Word Search Puzzle to The Fifth grade Students of SDN 01 Ngaglik Blitar in The Academic Year 2013/2014

Derin, T., \& Hamuddin, B. (2019). Foreign Language Classroom Anxiety, and Enjoyment During Study Abroad: A Review of Selected Paper. Lisan: Jurnal Bahasa dan Linguistik, 8(2), 76-82.

Derin, T., Nursafira, M. S., Yudar, R. S., Gowasa, N. S., \& Hamuddin, B. (2020). Persuasive Communication: What Do Existing Literature Tells Us About Persuasive Communication Among Students?. Utamax: Journal of Ultimate Research and Trends in Education, 2(1), 12-18.

Mohsen, K., Abdollahi, S., \& Omar, S. (2019). Evaluating the educational value of simulation games: Learners' perspective. Innovations in Education and Teaching International,56(4), 517-528.

Nuratika, S., Yanti, N. C. F., \& Mayer, E. (2019). Levels of Affixation in the Acquisition of English Morphology: A Review of Selected Paper. REiLA: Journal of Research and Innovation in Language, 1(2), 68-72.

Putri, S. E., Hamuddin, B., Nursafira, M. S., \& Derin, T. (2020). Discourse Analysis in E-LearningBased Course Using Moodle Platform: An Experimental Design. REiLA: Journal of Research and Innovation in Language, 2(1).

Rahman, F., Abbas, A., \& Hasyim, M. Facebook Group as Media of Learning Writing in ESP Context: A Case Study at Hasanuddin University. The Asian EFL Journal 26(6), 153-167.

Risani, T. D. (2020). Writing News Item in English Language Teaching Context: Line Apps Platform for Senior High School Students. Utamax: Journal of Ultimate Research and Trends in Education, 2(1).

Rizky, R. (2020). "Bits and Pieces" to Improve the Students' Writing Skill: Using Educational Game as an Approach to Teach Descriptive
Text. ELSYA: Journal of English Language Studies, 2(1).

Schmitt, N., \& Schmitt, D. (2020). Vocabulary in language teaching. Cambridge university press.

Seawright, J. (2016). The case for selecting cases that are deviant or extreme on the independent variable. Sociological Methods \& Research, 45(3), 493-525.

Troussas, C., Krouska, A., \& Sgouropoulou, C. (2020). Collaboration and fuzzy-modeled personalization for mobile game-based learning in higher education. Computers \& Education, 144, 103698. 